DOI https://doi.org/10.30525/978-9934-588-79-2-2.19

\title{
СУЧАСНІ АСПЕКТИ ФОРМУВАННЯ КРАФТОВИХ ПРОДУКТІВ У РЕСТОРАННІЙ СПРАВІ
}

\author{
Паска М. 3. \\ доктор ветеринарних наук, \\ професор кафедри готельно-ресторанного бізнесу \\ Львівського державного університету фізичної культури \\ імені Івана Боберського \\ Графська O. I. \\ кандидат економічних наук, \\ доцент кафедри готельно-ресторанного бізнесу \\ Львівського державного університету фізичної культури \\ імені Івана Боберського \\ Кулик О. М. \\ магістрантка \\ Львівського державного університету фізичної культури \\ імені Івана Боберського \\ м. Львів, Украӥна
}

На сьогодні структура харчування населення потребує розширення лінійки продуктів, які мають високі харчові та біологічні характеристики та $є$ оригінальними. Актуальність досліджень зумовлена створенням неповторних крафтових виробів виготовлених у Західному регіоні, які об'єднують у собі сучасні новітні досягнення у сфері здорового харчування, а також розвитку харчових технологій, ресторанного та туристичного бізнесу.

Аналіз літературних даних свідчить, що ще в Давньому Римі виноградних равликів високо цінували, як вишукане делікатесне блюдо і створювали спеціальні «равликові сади» - плантації капусти, на які равлики випускалися для інтенсивної відгодівлі. Відомо, що завдяки своїй харчовій цінності цей середземноморський продукт походить 3 країн Південної та Південно-Східної Свропи і широко поширився до Передньої і Середньої Азії, Північній Африці, Південній і Північній Америці, по країнах Західної Свропи, країнах Балтії $[1,2]$.

Впровадження крафтових продуктів, зазвичай це ресторанний бізнес, який є одним з найбільш розповсюдженим видом малого бізнесу, що робить його привабливим для інвесторів. 3 одного боку це однин 76 
iз засобів висококваліфікованого капіталу, а з іншого середовище із високим ступенем конкуренції, тому заклади ресторанного господарства ведуть один проти одного постійну конкурентну боротьбу за утримання постійних клієнтів та першості на ринку послуг. Розвиток ринку ресторанів в Україні, за останні кілька років, інтенсивно змінився. Сучасний ресторанний бізнес, як ніколи раніше, пропонує широку номенклатуру послуг споживачам продукції та послуг ресторанного господарства. Варто зауважити, що розвиток почався з верхнього, елітного цінового сегмента. Ще декілька років тому, успішні підприємства були розраховані на багату в той час аудиторію. 3 плином часу цей сегмент почав звужуватися, натомість з'явилися і почали розвиватися середньо-цінові кафе і ресторани, які потребують крафтової лінійки [3].

На сучасному етапі в Україні формується нова перспективна галузь тваринництва, де Львівщина є однією із лідерів із вирощування равликів. На сьогодні Львівщина є однією із лідерів із вирощування равликів, загалом на Львівщині уже зареєстровано 20 ферм равликів. М'ясо равликів $є$ дієтичним продуктом, ні в чому, не поступає курячому, оскільки містить величезну кількість корисних вітамінів, амінокислот і мікроелементів. У м'ясі равлика багато тваринного білка, кальцію, заліза.

Попит на равликів активно зростає, проте культура поїдання молюсків ще не настільки розвинена, як у СС, власне, тому і розробка нових видів делікатесних продуктів $є$ темою актуальною. Сучасні тенденції забезпечення якості та безпечності харчових продуктів орієнтовані на розроблення стандартизованих протоколів організації виробництва продукції [4].

Перспективною асортиментною групою сьогодні $\epsilon$ ніжне м'ясо равликів є дієтичним продуктом, ні в чому, не поступає курячому, оскільки містить величезну кількість корисних вітамінів, амінокислот $\mathrm{i}$ мікроелементів. У равлику багато тваринного білка, кальцію, заліза. Для створення делікатесних продуктів спеціального призначення була проведено аналіз із розширення міркувань про біологічні ресурси, як нові джерела сировини [5].

М'ясо равликів низькокалорійне і тому може використовуватися у дієтах. Якщо порівняти санітарно-гігієнічні показники м'яса, яке отримали від равликів, з м'ясом птиці чи жуйних тварин, то за більшістю показників воно є кращим[6,7] Так, у м'ясі слимаків вміст протеїну на рівні $14-16 \%$, а у птиці - 13-14\%. Вміст жиру у м'ясі піддослід- 
них слимаків на рівні $0,6-0,7 \%$, тоді як в філе яловичині $-10,5 \%$, а птиці-10\%[9].

Мета роботи: розробка крафтових продуктів шляхом створення конкурентоспроможного продукту на гастрономічному туристичному ринку.

При виконанні експериментальної частини роботи застосовували загальноприйняті і спеціальні методи визначення технологічних, органолептичних показників. Теоретико-аналітичні дослідження проводилися з використанням широкого спектру вітчизняних і зарубіжних спеціалізованих літературних джерел, а також всесвітньої інформаційної мережі «Інтернет».

При проведенні досліджень слугували равлики виду Helix pomatia, яких збирали в сиру погоду, після дощу, іноді вранці, були отримані 3 фермерського господарства «Західний равлик».

Перспективною асортиментною групою сьогодні є нові види делікатесних продуктів спеціального призначення. Для створення делікатесних продуктів спеціального призначення було проведено аналіз із розширення міркувань про біологічні ресурси, як нові джерела сировини. Ці особливості вказують, що м'ясо виноградних равликів характеризується високим вмістом амінокислот, швидким та повним засвоєнням, відсутністю холестеролу [6, 7].

У статті запропоновано технологію забою равликів та особливості переробки, які включають промивання, очищення, видалення з мушлі, сортування.

Технологія забою равликів та особливості переробки включають промивання, очищення, видалення з мушлі, сортування. Перед формуванням середньої проби м'яса равликів звертали увагу, перш за все, на їх стан: поведінку, реакцію на зовнішні подразники, рухливість, тобто відбирали лише живих. Для дослідів брали равликів, які в спокійному стані рухались, а у стресовому - ховалися у мушлю. Видаляли їх із мушлі та брали середню пробу.

Крім того, з'ясовано, що м'ясо равликів уважається придатним для споживання при проварюванні його протягом 90 хвилин, то для виготовлення напівфабрикатів або отримання м'ясного філе більш вигідніші равлики природньої популяції - Н. pomatia.

Розглянуті особливості впливу термічної обробки на вихід м'яса, з різним інтервалом часу. Запропоновано та розглянуто методику визначення виходу готового вареного продукту, враховуючи різний інтервал часу варіння. М'ясо равликів за ступенем готовності поділено на: сире (проварене протягом 30 хвилин), напівсире (проварене 
протягом 60 хвилин) та добре проварене (проварене протягом 90 хвилин).

За результатами наших досліджень можна стверджувати, що м'ясо равликів H. pomatia, за 30 хвилин уварюється (у \%) на 34,33; за 60 хвилин (у \%) на 35,11, та за 90 хвилин (у \%) на $36 \%$ відповідно, за своїми параметрами відповідає втратам маси під час термічної обробки телятини, наші результати узгоджуються із результатами досліджень Данілової I.C. [8].

Отже, підсумовуючи представлені дані досліджень роботи створенно конкурентоспроможний продукт на гастрономічному туристичному ринку, який полягав в розробці крафтових продуктів. Для реалізації поставлених завдань застосовували сучасні крафтові продукти Львівщини.

\section{Література:}

1. Виноградная улитка, Romansnail, Applesnail (Helixpomatia) [Електронний ресурс]. Режим доступу до ресурсу: https://zooclub.ru/ bezp/4/index.shtml

2. http://agroportal.ua/ua/views/blogs/ulitki-zavoevyvayut-svoyunishu-v-zhivotnovodstve

3. Паска М., Баль-Прилипко Л. Потенціал автентичних делікатесних м'ясних продуктів у контексті гастрономічного туризму: матеріали XII Міжнародної науково-практичної конференції. Проблеми активізації рекреаційно-оздоровчої діяльності населення (23-24 квітня 2020 р., м. Львів). Львів, 2020. C. 283-287. http://repository.ldufk.edu.ua/ handle/34606048/25795

4. Bal'-Prylypko, L.V., Slobodianiuk, N.M., Polishchuk, G.Ye., Paska, M.Z., Burak, V.Ye. Standardization, Metrology, Certification and Quality Management, Manual. Komprint. Kyiv: Komprint. 2017. 558 p.

5. Баль-Прилипко Л. Використання делікатесного м'яса ампулярій в оздоровчому харчуванні / Л. Баль-Прилипко, Л. Дерев'янко, О. Андрощук // Продовольча індустрія АПК. - 2017. - № 3. - С. 13-18.

6. Паска М.3 Порівняльна оцінка якості яловичини NOR, PSE та DFD. Східно-Свропейський журнал передових технологій. 2015. № 3(10). C. 59-60. DOI: https://doi.org/10.15587/1729-4061.2015.44496

7. Кравців Р.Й., Паска М.З., Личук М.Г. Технологічна оцінка хімічного складу яловичини при застосуванні мікроелементних добавок. Наукові праці. Одеса. 2006. Вип. 28. Т. 2. С. 34-36. 
6. Kausar, T., Hanan, E., Ayob, O. Eds A review on functional ingredients in red meat products. Bioinformation. 2019. 15 (5). P. 358-363. DOI: https://doi.org/10.6026/97320630015358

7. Umaraw, P., Chauhan, G., Mendiratta, S. K. Eds. Effect of oregano and bay as natural preservatives in meat bread for extension of storage stability at ambient temperature. Journal of Food Processing and Preservation. 2020. 44(4). doi: https://doi.org/10.1111/jfpp.14375

8. Данілова І. С., Данілова Т. М. Визначення увареності м'яса равликів. Вісник ПДАА. 2019. № 2. С. 133-139.

DOI https://doi.org/10.30525/978-9934-588-79-2-2.20

\title{
ОЦНКА КОНКУРЕНТОСПРОМОЖНОСТІ МАРШМЕЛОУ 3 АНТОЦІАНОВИМИ ДОБАВКАМИ
}

\author{
Пілюгіна I. C. \\ кандидат технічних наук, \\ доиент кафедри хімії, мікробіології та гігієни харчування \\ Харківського державного університету харчування та торгівлі \\ Артамонова М. В. \\ кандидат технічних наук, дочент, \\ доиент кафедри технології хліба, кондитерських, \\ макаронних виробів і харчоконцентратів \\ Харківського державного університету харчування та торгівлі \\ м. Харків, Україна \\ Одним із актуальних напрямів розвитку кондитерської галузі \\ України сьогодні $є$ виробництво продукції підвищеної харчової цінно- \\ сті та розширення асортименту шляхом використання натуральних \\ рослинних інгредієнтів. Науковцями активно проводяться досліджен- \\ ня щодо використання антоціанових рослинних добавок, у тому числі \\ кріодобавок, у технологіях мармеладно-пастильних виробів, пісочно- \\ го печива, дріжджових виробів тощо $[1,2]$. При цьому особлива увага \\ приділяється питанням якості та конкурентоспроможності нових ви- \\ дів виробів. \\ Вагомий вплив на конкурентоспроможність харчових продуктів \\ мають такі фактори як ціна, якість та безпечність. Тому визначення \\ органолептичних та фізико-хімічних показників, харчової цінності
}

